\title{
Ürün Yaşam Dönemi Maliyetleme Yönteminin İncelenmesi: Bir Vaka Analizi (Evaluating Product Life Cycle Costing Method: A Case Study)
}

\section{Ercüment OKUTMUŞ}

a Alanya Alaaddin Keykubat Üniversitesi, İşletme Fakültesi, Alanya, Antalya, Türkiye. ercument.okutmus@alanya.edu.tr

\begin{tabular}{|c|c|}
\hline MAKALE BİLGİSİ & ÖZET \\
\hline Anahtar Kelimeler: & \multirow{5}{*}{$\begin{array}{l}\text { Amaç - Ürün yaşam dönemi maliyetlemesi } 1950 \text { yllından itibaren kullanılan bir yöntem } \\
\text { olmakla birlikte günümüzde gelişen üretim teknolojisi ve değişen tüketim alışkanlıkları } \\
\text { sonucunda üretilen ürünlerin piyasada kalma süresi çok kısalmıştır. Bu rekabetçi piyasada } \\
\text { faaliyetlerini sürdürmek isteyen işletmeler çeşitli analiz yöntemlerini kullanarak maliyetlerini, } \\
\text { hangi ürünü üretip üretmeyeceklerini veya hangi ürün ya da makineyi satın alıp almayacakları } \\
\text { kararını vermektedirler. Bu nedenle konunun işletmeler açısından önemi ve güncelliği } \\
\text { nedeniyle çalışmada ürün yaşam dönemi maliyetlemesi analizi incelenmiş ve bir makine satın } \\
\text { alma kararında nasıl kullanılabileceği gösterilmiştir. }\end{array}$} \\
\hline Ürün & \\
\hline & \\
\hline Maliyet & \\
\hline Çağdaş Maliyet Yöntemleri & \\
\hline Gi & $\begin{array}{l}\text { Yöntem - İşletmeler açısından son derece önemli olan maliyet, satın alma verilerinin } \\
\text { toplanmasında gösterdiği hassasiyet nedeniyle çalışmada örnek vaka yöntemi kullanılmıştır. }\end{array}$ \\
\hline Revizyon Tarihi 18 Şubat 2019 & \multirow{2}{*}{$\begin{array}{l}\text { Bulgular - Çalışmada; EA7 Sadem isimli yazıcının Pax Seza 3D yazıcıya göre satın alma fiyatı } \\
\text { olarak ucuz olmasına rağmen, yaşam dönemi maliyetlemesi ile yapılan analiz sonucunda } \\
\text { işletmeye daha çok maliyet yükü bindireceği tespit edilmiştir. }\end{array}$} \\
\hline & \\
\hline Makale Kategorisi: & $\begin{array}{l}\text { Tartışma - Satın alma ve üretim kararı almadan önce ürün yaşam dönemi maliyetleme analizi } \\
\text { yapılmadığı durumlarda işletmeler ciddi kayıplarla karşılaşabileceğinden, bu analizler } \\
\text { yapılarak ilgili kararların verilmesi işletmeler için çok önem arz etmektedir. }\end{array}$ \\
\hline
\end{tabular}

\begin{tabular}{|c|c|}
\hline ARTICLE INFO & ABSTRACT \\
\hline Keywords: & \multirow{7}{*}{$\begin{array}{l}\text { Purpose - Product life cycle costing is a method, which has been employed since 1950s, and } \\
\text { during that period product life cycles have been remarkably shortened as a result of today's } \\
\text { advanced production technologies and changing consumption patterns. Businesses with desire } \\
\text { to carry on their operations, decide their costs, which products to manufacture and which not, } \\
\text { or which product or machinery to buy/not to buy by employing numerous analyzing methods. } \\
\text { Thus, due to the importance and the validity of this topic for the businesses, product life cycle } \\
\text { costing and how it can be employed during the decision making of purchasing of a machinery } \\
\text { has been analyzed in this article. }\end{array}$} \\
\hline Product Life Cycle Costing & \\
\hline & \\
\hline & \\
\hline Contemporary Cost Analysis & \\
\hline & \\
\hline Received 2 January 2018 & \\
\hline Revised 18 February 2019 & \multirow{2}{*}{$\begin{array}{l}\text { Design/methodology/approach - Sample case method has been employed since it displays } \\
\text { sensitivity on collecting data on costs and purchasing which are vital for businesses. }\end{array}$} \\
\hline Accepte & \\
\hline \multirow{3}{*}{$\begin{array}{l}\text { Article Classification: } \\
\text { Research Article }\end{array}$} & $\begin{array}{l}\text { Findings - In this study, it is confirmed that printer EA7Sadem brings more cost burden than } \\
\text { printer Pax Seza 3D, despite its purchasing cost is lower than Pax Seza 3D, by the results of the }\end{array}$ \\
\hline & analyses made on product life cycle costing. \\
\hline & $\begin{array}{l}\text { Discussion - Product life cycle costing analyses have become more of an issue during decision } \\
\text { making process of purchasing and production, since it may cause serious losses if mentioned } \\
\text { analyses are not carried out. }\end{array}$ \\
\hline
\end{tabular}

\section{Giriş}

Küreselleşme ve rekabetin küresel bir boyut kazanması, teknolojik gelişmeler, ürün yaşam dönemlerinin kısalması, pazara yeni rakiplerin girmesi, müşteri ihtiyaçlarının hızla değişmesi iş çevreleri karmaşık bir hale getirmiştir. Bilgi ve iletişim teknolojilerinin gelişmesiyle birlikte daha bilinçli hale gelen tüketiciler daha kaliteli ve fonksiyonel ürünleri daha düşük fiyata talep etmektedir. Bugün, işletmeler ürettikleri ürünleri müşteri taleplerine göre tasarlama ve üretmek zorundadırlar. 
Müşteri taleplerine göre ürün tasarım ve üretimi yapma zorunluluğunun yanında küresel rekabet baskısı altındaki işletmeler yüksek teknolojiler kullanarak üretim sistemlerini değiştirmek durumunda kalmış değişen üretim sistemlerine paralel olarak mevcut maliyet sistemlerini de değiştirme ihtiyacı doğmuştur. Geleneksel maliyet sistemleri bugünün yoğun rekabet koşullarında yetersiz kalmış ve daha etkin maliyet bilgileri üretmek için çağdaş maliyet sistemleri geliştirilmiştir. Bu sistemlerden biri de 1960'll yıllara ABD Savunma Bakanlığı tarafından geliştirilen ürün yaşam dönemi maliyetleme yöntemidir.

Ürün yaşam dönemi maliyetlemesi, bir ürünün tasarım aşamasından elden çıkarılmasına kadar katlanılan maliyetlerini ayrı ayrı hem üretici hem tüketici açısından bakan, ürünlerin yaşam dönemi maliyetlerini tasarım aşamasındayken belirleyen ve böylece karar alma sürecine destek olan bir maliyetleme yöntemidir. Bu kapsamda çalışmanın amacl, ürün yaşam dönemi maliyetleme yönteminin bir ürünün satın alınıp alınmaması kararına etkisini incelemektir.

\section{Kavramsal ve Kuramsal Çerçeve}

\subsection{Temel Tanım ve Kavramlar}

İşletmeler, yeni bir ürünü piyasaya sunduktan sonra ürünün piyasada tutunmasını, yer etmesini, uzun süre piyasada kalmasını ve karlı olmasını talep etmektedirler. Her ürünün piyasaya girmesi ile başlayan ve piyasadan çekilmesi ile son bulan bu döneme ürün yaşam dönemi denilmektedir. Her bir ürünün yaşam dönemi değişiklik göstermekte, kısa olabileceği gibi uzun da olabilmektedir (Caner, 2011: 46).

Ürün yaşam dönemi maliyetleme yöntemi ise, bir ürünün yaşam dönemi boyunca ortaya çıkan maliyetleri üretime başlamadan önce belirlemeye çalışan bir yaklaşım (Güneş ve Aksu, 2008: 44; Luo ve diğerleri, 2009: 1614) olup, işletmenin hedeflerine yönelik etkin bir planlama aracı, maliyetleme yöntemi ya da pazarlama stratejisinin belirlenmesinde kullanılan bir yönetim yaklaşımı olarak tanımlanmaktadır (Otlu ve Karaca, 2005: 249).

Üretilecek bir ürün, sistem ya da varlığın yaşam dönemi boyunca katlanılacak maliyetlere odaklanan bir yöntem olan ürün yaşam dönemi maliyetlemesi ilk olarak 1960'lı yıllarda ABD Savunma Bakanlı̆̆1 tarafından tedarik sürecinde stratejik bir karar verme aracı olarak geliştirilmiştir (Dunk, 2004, s.402; Korpi ve Ala-Risku, 2008, s.242). 1960'lardan sonra özellikle 1980'li yıllarda yoğun rekabet nedeniyle geliştirilerek ticari alanda kullanılmaya başlanmışır (Dunk, 2004, s.402). 1960'lardan 1980'lere kadar askeri amaçla kullanılan yöntem 1980'lerden itibaren başta havacılık, enerji, petrol, demiryolları olmak üzere birçok sanayi kolunda yaygın bir şekilde kullanılmış ve kullanılmaktadır (Deran, 2008: 467). Yaşam dönemi maliyetlerinin azaltılması düşüncesi ilk olarak Entegre Lojistik Destek Programı çerçevesinde gündeme gelmiş, yöntem zamanla geliştirilerek üretim, işletim, bakım ve diğer sahip olma maliyetlerinin hesaplanmasında yeni bir anlayış getirmiştir (Kawauchi ve Rausand, 1999: 5).

Yöntem, çoğunlukla karar alma sürecinde gerek duyulan ve bir ürünün yaşam dönemi boyunca ürün ile ilgili işletmenin katlanacağı her türlü maliyeti ve maliyet unsunu oluşturan faaliyetleri tanımlayan, bu maliyetleri tahmin eden, raporlayan ve planlama aşamasında ürün karlılığını artırmak için çeşitli önlemler alınmasını amaçlayan bir yönetim karar aracıdır. Dolayısıyla fiyatlama kararlarının verilmesi ve ürün karlılığının belirlenmesinde karar alma sürecine destek olmaktadır (Çiftçi, 2012: 32).

Ürün yaşam dönemi maliyetleri üretim öncesi, üretim süreci ve üretim sonrası olmak üzere 3 temel gruba ayrılabileceği gibi (Deran, 2008: 466; Gersil, 2006: 131) aynı zamanda işletmeler arası farklılık göstermekle birlikte aşağıdaki temel maliyet gruplarından oluşmaktadır (Ayyıldız, 2010: 37):

- Araştırma-geliştirme maliyetleri,

- Tasarım maliyetleri,

- Sunuş maliyetleri,

- Üretim maliyetleri,

- Satış ve lojistik maliyetleri,

- Servis ve garanti maliyetleri,

- Kullanım maliyetleri. 
Üretim öncesi aşaması ürün fikrinin ortaya çıkmasıyla başlamakta, üretilecek ürünle ilgili tüketici taleplerini ortaya koyacak piyasa araştırması yapılmaktadır. Üretim süreci ve ürün bileşenlerini oluşturan parçalar bu aşamada belirlendiği için mühendisler, tedarikçiler ve tasarım ekibi arasındaki işbirliğinin önemi bu aşamada ortaya çıkmaktadır. Bu aşamada verilecek kararlar sonucunda ürünün yaşam dönemi boyunca göstereceği performans belirlenmiş olmaktadır (Caner, 2011: 76). Ürünler, azami sayıda fonksiyonlarını yerine getirecek şekilde tasarlanmalı ve parçalar mümkün olduğunca standartlaştırılmalıdır. Tasarım değişiklikleri ürün piyasaya sunulduktan sonra yapılabilse de değişikliklerin ilk tasarımda gerçekleştirilmiş olmasının işletmeye sağlayacağı kar avantajı kaçırılacaktır (Erden, 2004: 206). Dolayısıyla, tasarım değişikliğinin üretime geçildikten sonra yapılması üretime geçilmeden yapılmasından daha maliyetli olmaktadır. Çünkü üretim öncesi maliyetler; sadece araştırma geliştirme maliyetleri, tasarım maliyetleri ve deneme üretimi maliyetlerinden oluşmaktadır (Caner, 2011: 76).

Üretim sürecinde ortaya çıkan maliyetler; endüstriyel mühendislik ve faaliyet analizleri, tesis yapımı, üretim faaliyetleri, kalite kontrol ve lojistik, yedek parça üretimi, test ve destek ekipmanlarının üretimi gibi faaliyetler sonucunda ortaya çıan maliyetlerden oluşturmaktadır. Üretim sürecinde en önemli faktör, etkin bir maliyet planlaması ve kontrolü ve gelişen üretim tekniklerinden yararlanarak maliyetleri düşürebilmektir. $\mathrm{Bu}$ aşamada oluşan maliyetler ürünün toplam maliyetinin önemli bir kısmını oluşturmaktadır (Caner, 2011: 80).

Üretim/Satış sonrası ortaya çıkan maliyetler, tüketici satın aldıktan sonra bir ürünün kullanımı, bakım onarımı ve hurdaya ayrılmasına kadar olan yaşam dönemini kapsamakta olup, ürünün tüketici faaliyetleri, ürün pazarlama, satış, aşıma vb faaliyetler, lojistik destek faaliyetlerinin maliyetlerinden oluşmaktadır (Caner, 2011: 84).

Ürün yaşam dönemi maliyetleri ayrıca üretici ve tüketici bakış açısıyla olmak üzere ikiye ayrılmaktadır (James, 2003: 66; Goralczyk ve Kulczycka, 2005: 120; Emblemsvag, 2003: 16). Tüketici bakış açısıyla ürün yaşam dönemi maliyetleri bir ürünün yaşam dönemi boyunca tüketicinin katlandığı tüm maliyetlerdir. Bunlar; satın alma maliyeti, kurma/montaj maliyeti, kullanma maliyeti, destekleme maliyeti, bakım/onarım maliyeti ve elden çıkarma maliyetidir. Bu maliyetlerin belirlenmesinde ürün kalitesi oldukça önemlidir ve dikkate alınması gerekir (Güneş ve Aksu, 2003: 44; Emblemsvag, 2003: 16-17). Üretici bakış açısıyla ürün yaşam dönemi maliyetleri üreticinin bir ürünün yaşam dönemi boyunca katlandığı tüm maliyetleri ifade etmektedir. Bunlar; ürün fikrini oluşturma maliyeti, tasarım maliyeti, ürün ve süreç geliştirme maliyeti, üretim maliyetleri, lojistik maliyetleri, pazarlama maliyetleri, hizmet ve garanti maliyetleridir (Altınbay, 2006a: 96-97; Ayy1ldız, 2010: 33; Emblemsvag, 2003: 16).

Her ürün yaşam dönemi boyunca sunuş, büyüme, olgunluk ve düşüş döneminden geçmektedir (Ayyıldız, 2010: 28; Caner, 2011: 52). Sunuş döneminde üretim kapasitesinin genişletilmesi ile ilgili teknik sorunlar ve fiziksel dağıtım güçlükleri nedeniyle satışlar yavaş büyümektedir (Gül, 2004: 5). Bu dönemde ürün piyasaya yeni girdiği için işletmenin amacı tüketici ile buluşmak ve en yüksek tüketici oranına ürünü denetmektir. Bu amaçla reklam, satış promosyonları, fuarlara katılma vb tanıtım faaliyetleri yapılmaktadır (Caner, 2011: 54). Büyüme döneminde tutundurma maliyetleri aynı kalmakta ya da az bir oranda artmakta, bu maliyetlerin yüksek miktardaki satışlara yayılmasıyla birim üretim maliyetleri düşmekte ve karlılık artmaktadır (Gül, 2004: 5). Büyüme dönemi, satışların artmaya başladığı, toplam katkı payının sabit giderleri aştığı bir dönemdir. Birim sabit giderler düşmekte ve piyasaya yeni rakipler girmeye başlamaktadır (Ayyıldız, 2010: 29). Olgunluk döneminde ürün piyasada iyi tanınmakta ancak satışlarda duraklama başlamaktadır. Dolayısıyla üreticilerin karı düşmeye başlamaktadır. İşletmeler arası rekabet artarken ürün talebine olan artış hızında düşüş olmaktadır. Satış ve karların düşmesi ve tutundurma maliyetlerinin yüksek olması nedeniyle işletmeler arasındaki rekabet, fiyat ve tutundurma ile yapılmaktadır. Bu dönemde yoğun rekabet nedeniyle ürün farklılaştırma ve ek hizmetler yapılmaktadır (Caner, 2011: 55). Düşüş dönemi, satışlarda ve karda azalma birim sabit maliyetlerde artışın olduğu bir dönemdir (Ayyıldız, 2010: 30). Düşüş döneminde ikame ya da farklı ürünler orijinal ürün yerine geçmek üzere piyasaya girmiştir. Satışların düşmesiyle birlikte karlılıkta düşmektedir (Gül, 2004: 6).

\section{2. Ürün Yaşam Dönemi Maliyetlemesi Analiz Süreci}

Ürün yaşam dönemi maliyet analizi ifadesiyle ürün yaşam dönemi maliyetlemesi kastedilmektedir. Bu analiz yöntemin ayrılmaz bir parçası olup analiz sonucu elde edilen verilerle birim ve toplam maliyetler 
belirlenmektedir. Analiz yapılmadan maliyetleme yapılamamakta; maliyet sonuçları analiz yapılmadan değerlendirilememektedir. Şekil 1'de bu süreç gösterilmektedir (Yılmaz ve Arı, 2011: 79).

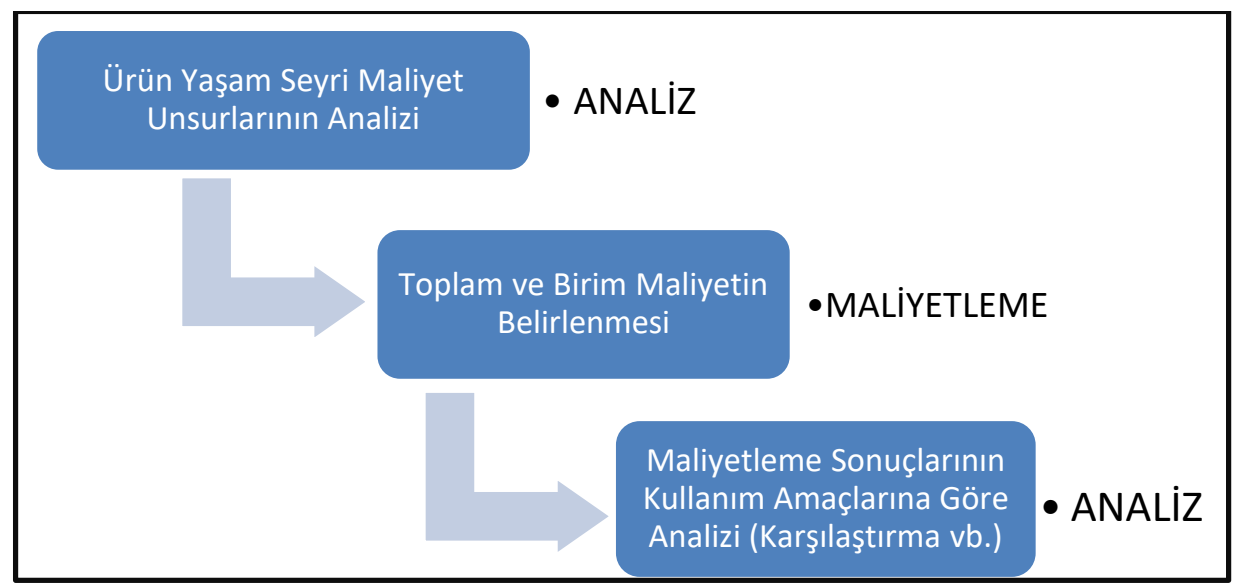

Şekil 1 Ürün Yaşam Dönemi Analiz Süreci ve Maliyetleme İlişkisi Kaynak: Yılmaz ve Arı, 2011: 80

Ürün yaşam dönemi analiz süreci bir ürünün yaşam dönemi içindeki tüm aşamalarda yöneticilerin alacağ1 optimal pazarlama ve üretim kararlarıla işletmenin maksimum karlılık seviyesine ulaşmasını hedeflemektedir. Ürün yaşam dönemi, ürün yaşamının sınırlı olduğu farklı pazarlama, üretim ve finansman fonksiyonlarına gereksinim duyulan, yönetsel bir kontrol aracı olarak işletmenin ürün, maliyet ve karlılığının ortaya konulduğu bir süreçtir (Caner, 2011: 56).

Ürün yaşam dönemi analizi, maliyetlerin enflasyon oranında artırılması, enflasyon oranında artırılan maliyetlerin bugünkü değerinin hesaplanması ve duyarlılık analizi olmak üzere üç aşamadan oluşmaktadır (Caner, 2011: 63).

a) Ürün yaşam dönemi maliyetlemesinde analiz yapılırken birden fazla dönem analize dahil edildiği için enflasyon faktörünün göz önüne alınması gerekir. Enflasyon nedeniyle ürün maliyetlerinde de değişiklik olacak; ürün maliyetleri yükselirken, paranın satın alma gücü ise düşecektir. Enflasyon hesaplamaları yıldan yıla değişiklik göstereceği için belirli bir yıl referans alınarak sabit paranın alım gücü paranın referans alındığı yıldaki alım gücünü gösterecek şekilde hesaplama yapılmaktadır (Caner, 2011: 63).

b) Ürün yaşam dönemi maliyetlemesinde tüm maliyetler uygun bir iskonto oranı kullanılarak şimdiki değere çevrilmektedir. Şimdiki değer hesaplamanın nedeni herhangi bir yılda ortaya çıkacak maliyetlerin ilk yıldaki maliyetlerle aynı olmamasıdır. Örneğin 10. yılın maliyetleri ile başlangıç yılındaki maliyetlerin bugünkü değeri farklı olacaktır (Gersil, 2006: 87).

c) Ürün yaşam dönemi maliyetlemesinde maliyetleri üzerinde etkili olan diğer bir faktör de öğrenme etkisidir. Deneyim etkisi olarak da adlandırılan öğrenme etkisi, yapılan işlerin tekrarlanarak öğrenimlerin sonucu işte hızlanılması, deneyim kazanılması ve dolayısıyla performanstaki artışı ifade etmektedir. Çalışanların deneyimleri arttıkça verimlilik artacağı için birim başı maliyetler düşecektir. Ürün yaşam dönemi analizi veri toplarken yapılan varsayım ve hesaplamalara dayanmakta ve varsayım ve hesaplamalarla ilgili olarak belirsizlik bulunmaktadır. Bu hesaplamaların doğruluğunun tarihi veriler ve istatistiksel analizlerle artırılması mümkün olsa bile her bir varsayım için duyarlılık analizinin yapılması gerekir (Caner, 2011: 64-65).

Ürün yaşam dönemi maliyetleme süreci aşağıda açıklandığı gibi 11 aşamadan oluşmaktadır (Barringer, 2003: $4)$ :

1. Aşama: Nelerin analiz edileceği ve yaşam sürecinde hangi çalışmaların yapılacağı belirlenmektedir.

2. Aşama: Alternatif çözümler aranırken teknik özelliklerin ekonomik sonuçları değerlendirilmektedir.

3. Aşama: Yıl belirtilerek maliyet ayrıntılandırılması yapılmaktadır.

4. Aşama: Uygun maliyet modeli ve projenin gerektirdiği ayrıntılar belirlenmektedir.

5. Aşama: Maliyet ayrıntıları edinilmektedir. 
6. Aşama: Yıllık maliyet profili çıkarılmaktadır.

7. Aşama: Zaman ve para açısından ayrıntıları belirlemek için başabaş çizelgeleri oluşturulmaktadır.

8. Aşama: Pareto dağılımı içindeki büyük maliyet dağılımları belirlenmektedir.

9. Aşama: Bakım ve onarım maliyetleri planlananın $\pm \% 10$ şeklinde gerçekleşirse yüksek maliyetli seçenekler denenmektedir.

10. Aşama: Hata analizleri yapılarak alternatifler değerlendirilmektedir.

11. Aşama: Tercih edilen proje seçilerek çizelgelerle belirtilmektedir.

Yaşam dönemi maliyetleme sürecinin 11 aşamasının yukarıda belirtilen sıralamasında görüldüğü üzere, bir maliyet kaleminin elde etme ya da sürdürme maliyeti olup olmadığının belirlenmesi ancak hangi alanlarda kullanıldığının belirlenmesi ile yapılabilmektedir. Elde etme ve sürdürme maliyetleri, doğru girdilerin bulunması, girdi veritabanlarının oluşturulması, ürün yaşam dönemi maliyetlemesinin değerlendirilmesi ve maliyet etkenlerinin belirlenmesi ile saptanmaktadır (Barringer, 2003: 5).

Mamul yaşam dönemi maliyetleme yöntemi uzun dönemli bir plana ve tahminlere dayanmasından dolayı mamulün yaşam dönemi maliyetinin hesaplanabilmesi için bazı kavramlara ihtiyaç duyulmaktadır (Çiftçi, 2012: 53). Ürün yaşam dönemi maliyetlerinin hesaplanmasında kullanılan bu kavramlar (Güneş ve Aksu, 2003: 49):

- Başlangıç yatırım maliyetleri,

- Varlığın ömrü,

- İskonto oran1,

- Net şimdiki değer,

- İşletme ve bakım onarım maliyetleri,

- Bilgi ve geri besleme,

- Hurda maliyetleri,

- Belirsizlik ve duyarlılık analizi.

Başlangıç Yatırım Maliyeti: fiziksel varlığın satın alınmasından başlayarak faaliyete geçirinceye kadar katlanılan tüm maliyetleri olup, satın alma, elde etme ve kurulum maliyetlerini içermektedir (Güneş ve Aksu, 2003: 50).

Varlı̆̆ın Ömrü: fonksiyonel ömür, fiziksel ömür, teknolojik ömür, ekonomik ömür, sosyal-yasal ömür olmak üzere beşe ayrılmaktadır (Ayyıldız, 2010: 35; Barringer, 2003: 5; Dunk, 2004: 338; Otlu ve Karaca, 2005: 263):

- Fonksiyonel Ömür: varlığın işletme faaliyetlerinde gereksinim duyulduğu süredir.

- Fiziksel Ömür: fiziki olarak varlığın ömrünün tükenmesinin beklendiği, fiziksel olarak yenilenme ihtiyacının ortaya çıktığı süredir.

- Teknolojik Ömür: İleri teknolojili bir alternatifin ortaya çıkmasıyla varlığın yenilenmesini gerektiren teknolojik eskime süresidir.

- Ekonomik Ömür: daha düşük maliyetli bir alternatifle varlığın yenilenmesinin gerektiği ekonomik eskime süresidir.

- Sosyal ve Yasal Ömür: varlığın tüketici isteği ya da yasal gerekçelerle yenilenmesinin gerekeceği zamana kadar geçen süredir.

İskonto oranı: ürün yaşam dönemi maliyetlerinin bugünkü değere indirgenmesinde uygun iskonto oranının seçimi oldukça önemlidir. Iskonto oranının paranın kazanma gücünü ve enflasyonun etkilerini yansıtması gerekmektedir (Çiftçi, 2004: 56; Güneş ve Aksu, 2003: 50). Uygun bir iskonto oranı, işletmenin fırsat maliyetlerini karşılayacak bir oran kadar, yabancı kaynakları için ödeyeceği faiz kadar ya da endüstriyel borçlanmalarda katlandığı faiz oranının büyüklüğünde olmalıdır (Caner, 2011: 72).Ürün yaşam dönemi 
maliyetlemesinde iskonto oranları aşağıdaki yöntemlerle belirlenebilmektedir (Ayyıldız, 2010: 35; Dunk, 2004: 338):

- İşletmenin kullandığı fonlar için ödeme yapacağı mevcut ya da beklenen faiz oranı,

- İşletmenin başka bir proje yatırımından beklediği getiri oranı (fırsat maliyeti),

- Enflasyon oranının düşük olduğu varsayımına dayanan test bir iskonto oranı,

- İşletmenin faaliyet gösterdiği sektördeki en düşük borçlanma oranı,

- Hazine bonosu faiz oranı ile beklenen enflasyon oranı arasındaki fark iskonto oranı olarak hesaplanabilir.

Net Şimdiki Değer: belirli bir dönem süresince bir faaliyet için gelecekteki tahmini maliyetlerin şimdiki değeri ile gelecekteki tahmini gelirin şimdiki değeri arasındaki farkı ifade etmektedir (Otlu ve Karaca, 2005: 264). Ürün yaşam dönemi maliyetlemesinde tüm maliyetler net şimdiki değer yöntemi ile uygun bir iskonto oranı kullanılarak şimdiki değere indirgenmektedir (Barringer, 2003: 4; Caner, 2011: 72).

İşletme ve Bakım Onarım Maliyeti: Ürün yaşam dönemi maliyetlerinin düşürülmesinde işletme ve bakım onarım giderlerinin rolü oldukça önemlidir. İşletme maliyeti direkt işçilik, direkt ilk madde ve malzeme, endirekt işçilik ve endirekt madde ve malzeme maliyetlerini içerirken; bakım onarım maliyetleri ise endirekt işçilik, yedek parça, enerji ve satın alma maliyetlerini kapsamaktadır (Güneş ve Aksu, 2003: 51).

Hurda Maliyetleri: Bir varlığın yaşam dönemi sonunda hurdaya ayrılması nedeniyle ortaya çıkan maliyetler olup varlığın yıkılması, ortadan kaldırılması vb işlemler için gerekecek tutarlar olabileceği gibi varlığın satılarak gelir elde edilmesi de olabilmektedir (Ayyıldız, 2010: 36).

Bilgi ve Geri Besleme: Ürün yaşam dönemi maliyetleme yönteminde bilgi ile kastedilen işletme ya da muhasebe açısında gerekli olan ve kullanılan bilgidir. Muhasebe açısından gerekli olan bilginin parasal olarak ifade edilmesi olup, varlığın satın alınması, tasarımı ve işletilmesinin sermaye maliyetine dair finansal zaman ve kalite verilerini içermektedir (Güneş ve Aksu, 2003: 51-52).

Belirsizlik ve Duyarlılık Analizi: Ürün yaşam dönemi maliyetleme analizi yapılırken girdi verilerinin yetersizliği nedeniyle oluşacak belirsizliklerle ilgili kritik parametreler ortaya çıkabilmekte, bu değişik parametrelerdeki varyasyonlara karşı sonuçların ne kadar duyarlı olduğunun belirlenmesi de gerekmektedir. Duyarlılık analizinin kapsamı konusunda fikir birliği olmasa da genelde enflasyon oranı, iskonto oranı, ürün talep oranı, ürün dağıtım zamanı, bakım faktörünün sıklığı gibi faktörlerin duyarlılık analizinde değerlendirilmesi gerekmektedir (Gersil, 2006: 85-86). Duyarlılık analizinde, ürün yaşam dönemi maliyetlemesine ilişkin veri toplanması aşaması yapılan varsayım ve hesaplamalara dayanmaktadır. Yapılan hesaplamaların doğruluğu statiksel yöntemlerle artırılabilse de her zaman belirsizlikler oluşabilmektedir (Ayyıldız, 2010: 36).

Ürün yaşam dönemi maliyetleme yönteminin işletmelerde kullanılmasında genel olarak görülen dört temel amacı bulunmaktadır. Bu amaçlar aşağıdaki gibidir (Ayyıldız, 2010: 33; Otlu ve Karaca,2005:252):

- Planlama ve pazarlama aşamasında ortaya çıkan maliyetlerini içeren faaliyet karının ürünün piyasada aktif olduğu aşama ya da üretim aşamasında kazanılıp kazanılmayacağını belirlemek,

- Planlama aşamasında üretim ile ilgili olmayan ürünle birlikte verilen garanti vb maliyetleri tanımlamak ve bu maliyetleri minimize etmek için yapılması gereken tasarım değişikliklerini belirlemek,

- Planlama bölümünde çalışanlara ürün tasarımına dair yaşam dönemi maliyetlerini karşılaştırarak bu alternatifler arasında en iyi seçimi yapabilmeleri için desteklemek ve

- Etkin bir planlama yapmak ve faaliyetleri kontrol etmek için maliyetlerin niteliklerini ve zamanlamasını tanımlamaktır.

$\mathrm{Bu}$ amaçların yanında ürün yaşam dönemi maliyetlemesinin işletmeler tarafından kullanıldığında elde edecekleri faydalar aşağıdaki gibi özetlenmektedir (Gürdal, 2007: 85):

- Bir ürünü üretmeye ilişkin alternatifler arasında seçim yapmaya yardımcı olur, 
- Gelecekteki maliyetleri tahmin etmeye destek olur ve böylece hem sermaye maliyeti hem de tüm maliyetlerin dikkate alınmasını sağlar,

- Üründen en yüksek faydanın elde edilmesini sağlar,

- Fiyatlandırmaya yönelik daha gerçekçi analiz yapılmasını sağlar,

- Gelecekteki harcamalar için bütçelemeye temel oluşturur ve böylece gelecekteki harcamaları belirlemeye ve bunları dengelemeye yardım eder,

- Ürün yaşam dönemine ilişkin gerçek tutarların ortaya çıkmasıyla birlikte fiili ve bütçelenen rakamların karşılaştırılmasına olanak sağlar,

- Tüketici satın alma kararlarını etkileyen garanti, yedek parça satışı, servis ve bakım gibi satış sonrası hizmetler ve maliyetlerin daha detaylı dikkate alınmasını sağlar ve

- Tasarım ve ürün geliştirme aşamalarında daha fazla maliyete katlanarak, üretim ve üretim sonrası aşamalarda daha az maliyete katlanılmasına yardım eder.

Ürün yaşam dönemi maliyetleme yönteminde, ürünün planlama aşamasında ürünle ilgili yaşam dönemi boyunca ortaya çıkabilecek tüm maliyetlerin tahminlenmesi, planlama ve kontrolüne olanak vermesi yöntemin önemini ortaya koymaktadır (Çiftçi, 2012: 32).Yöntemin temelinde yatan fikir, ürün yaşam döneminin tüm aşamalarında yöneticilerin alacağı kararlara destek olmak ve işletme karını maksimize etmektir. Bu bakımdan yöntem, işletmenin hem fonksiyonel maliyetleri üzerinde hem de strateji çalışmaları üzerinde önemli bir analiz tekniğidir (Otlu ve Karaca, 2005:249). Ürün yaşam dönemi maliyetlemesi özellikle yaşam dönemi kısa olan ürünler açısından önem taşımaktadır. Çünkü yaşam dönemi kısa olan ürünlerin piyasadan çekildikten sonra bu ürünler için yapılan maliyetleri karşılamak ve hedeflenen kar düzeyine ulaşmak oldukça önemlidir. Yaşam dönemi kısa olan ürünlerde uzun yaşam dönemine sahip ürünlerde olduğu gibi fiyatlandırma politikalarında ya da ürün karmasında değişiklik yapmak çok mümkün olmamaktadır (Erden, 2004: 207).

\section{3. Ürün Yaşam Dönemi Maliyetine İlişkin Bir Örnek Uygulama}

\subsection{Araştırmanın Tanıtımı, Yöntemi ve Kısıtları}

Çalışmada işletmelerin paylaşmak istemediği verileri olan maliyet verilerine ulaşmak gerektiğinden ve bu durumun zorluğu nedeniyle araştırma yöntemi olarak örnek vaka çalışması seçilmiştir. Çalışmada kullanılan işletme lüks üretim yapan ve farklı ölçeklerde 12 ürün üreten bir işletmedir. İşletmenin verilerini ve süreçlerini saklamak istemesi sebebiyle işletme adı saklı tutulmuştur. Fakat satın alma ve üretim karar aşamaları ile ilgili genel müdür ile görüşüldükten sonra piyasa araştırması yapılarak veriler değiştirilerek kullanılmıştır. Teknolojik gelişmeler ışığında ürünlerde kullanılması için üretilen temel parçaların daha düşük maliyetli olacağı kararıyla ürünlerde kullanılacak 3 adet parçanın 3D yazıcı ile üretilmesine karar verilmiştir. İşletme yaptı̆̆ı satın alma araştırmasında EA7 Sadem ve Pax Seza olmak üzere 2 adet farklı 3D yazıcı üzerinde karar vermek istemektedir. Bu nedenle yazıcılar arasında bir tercih yapacağından, en optimal tercihin hangisi olacağını saptamak istemektedir.

İşletmenin satın alma tercihi ürün yaşam dönemi maliyetlemesi ile analiz edileceğinden, işçilik ve direkt ilk madde/malzeme maliyetlerinin yıllara göre sabit kalacağı varsayılmıştır. Kullanılan iskonto oranı ise Türkiye İş Bankası'nın internet sitesindeki hazine bonosu ve devlet tahvilleri 2018 yılı oranı olan \%19,9 rakamı yuvarlanarak \%20 olarak baz alınmıştır (İşbankası, 2018). Net bugünkü değerin bulunmasında yıllara göre uygulanacak katsayılarda ise Çubuk (2018)'in oluşturduğu tablodan yararlanılmıştır.

\subsection{Analiz ve Bulgular}

İşletmenin yaptığı satın almaya ilişkin araştırma sonucunda elde edilen veriler yukarıda Tablo 1'de gösterilmiştir. Tabloda alış bedelleri ve alış masrafları görülmektedir ve alış masrafları ürünün işletmeye taşınması, bu süreçteki sigortası ve kurulum maliyetlerinden oluşmaktadır. 
E. Okutmuş 11/1 (2019) 216-226

Tablo 1 Satın Alma Maliyeti Tablosu

\begin{tabular}{|c|c|c|}
\hline \multicolumn{3}{|c|}{ Alış Maliyeti Tablosu } \\
\hline & $\begin{array}{c}\text { EA7 Sadem } \\
\text { 3D Yazıcı }\end{array}$ & $\begin{array}{l}\text { Pax Seza } \\
\text { 3D Yazıcı }\end{array}$ \\
\hline Alış Bedeli & $359.000,00$ も & $381.000,00$ も \\
\hline Alış Masrafları & $25.000,00 €$ & $17.000,00 €$ \\
\hline TOPLAM ALIŞ MALIYETI & $384.000,00 €$ & $398.000,00 €$ \\
\hline
\end{tabular}

Aşağıda Tablo 2'de ise EA7 Sadem 3D Yazıcı ile Pax Seza 3D Yazıcıların işçilik, ilk madde ve malzeme ile bakım ve onarım maliyetleri görülmektedir. Yıllara yayılan bu maliyetler 3D yazıcıların satın alma yılı olan 2018 cari fiyatları ile tabloda görülmektedir. İşçilik ile direkt ilk madde ve malzemelerin maliyetinin aynı olmasının sebebi 2 alternatif makinede de aynı parçaların aynı miktarda üretilecek olması ve aynı sayıda işçinin aynı ücretle çalışıyor olmasıdır. Bakım ve onarım gideri ise makinelerin markasına göre ilgili firmadan alınan değişkenler ile belirlenmiştir. Dolayısıyla iki makine arasında bakım ve onarım giderleri açısından farklılıklar bulunmaktadır.

Tablo 2 İşletmenin 3D Yazıcıların Kullanım Ömrü Boyunca Katlanacağı Maliyetler

\begin{tabular}{|c|c|c|c|c|c|c|}
\hline \multirow[b]{2}{*}{ Yillar } & \multicolumn{3}{|c|}{ EA7 Sadem 3D Yazıcı } & \multicolumn{3}{|c|}{ Pax Seza 3D Yazıcı } \\
\hline & $\begin{array}{c}\text { İşçilik } \\
\text { Maliyeti }\end{array}$ & $\begin{array}{c}\text { ílk Madde ve } \\
\text { Malzeme } \\
\text { Maliyeti } \\
\end{array}$ & $\begin{array}{c}\text { Bakım ve } \\
\text { Onarım } \\
\text { Maliyeti }\end{array}$ & İşçilik Maliyeti & $\begin{array}{c}\text { İlk Madde ve } \\
\text { Malzeme } \\
\text { Maliyeti } \\
\end{array}$ & $\begin{array}{c}\text { Bakım ve } \\
\text { Onarım } \\
\text { Maliyeti }\end{array}$ \\
\hline 2018 & $132.000,00 €$ & $280.000,00 €$ & $10.000,00 €$ & $132.000,00$ E & $280.000,00 €$ & $6.000,00$ छ \\
\hline 2019 & $132.000,00$ も & $280.000,00$ も & $15.000,00 €$ & $132.000,00$ є & $280.000,00$ も & $8.000,00$ छ \\
\hline 2020 & $132.000,00 €$ & $280.000,00 €$ & $17.000,00 €$ & $132.000,00 €$ & $280.000,00 €$ & $8.000,00$ も \\
\hline 2021 & $132.000,00 €$ & $280.000,00 €$ & $20.000,00 €$ & $132.000,00 €$ & $280.000,00 €$ & $9.000,00$ 至 \\
\hline 2022 & $132.000,00 €$ & $280.000,00 €$ & $23.000,00 €$ & $132.000,00 €$ & $280.000,00$ も & $11.000,00$ छ \\
\hline 2023 & $132.000,00 €$ & $280.000,00 €$ & $25.000,00 €$ & $132.000,00 €$ & $280.000,00 €$ & $12.000,00 €$ \\
\hline 2024 & $132.000,00 €$ & $280.000,00$ も & $27.000,00 €$ & $132.000,00 €$ & $280.000,00 €$ & $13.000,00$ も \\
\hline TOPLAM & $924.000,00 €$ & $1.960 .000,00 \leftleftarrows$ & $137.000,00 €$ & $924.000,00 €$ & $1.960 .000,00 \leftleftarrows$ & $67.000,00$ t \\
\hline
\end{tabular}

Tablo 2'de görülen EA7 Sadem 3D Yazıcının elde etme bedeli hariç işletmeye kullanım ömrü boyunca toplam maliyeti 3.021.000 TL (924.000+1.960.000+137.000)'dir. Pax Seza 3D Yazıcının elde etme bedeli hariç işletmeye kullanım ömrü boyunca toplam maliyeti ise 2.951.000 TL (924.000+1.960.000+67.000)'dir. Bu tutarlara Tablo 1'de görülen toplam alış maliyetleri de eklenir ise EA7 Sadem 3D Yazıcının maliyeti 3.405.000 TL, Pax Seza 3D Yazıcının maliyeti ise 3.349.000 TL olduğu görülecektir. 2 alternatif arasındaki fark 56.000 TL olarak görülmektedir. Bu maliyetler net bugünkü değere indirgenmemiş cari değerlerdir.

Tablo 3 İşletmenin 3D Yazıcıların Kullanım Ömrü Boyunca Katlanacağı Maliyetlerin Net Bugünkü Değeri

\begin{tabular}{|c|c|c|c|c|c|c|c|}
\hline \multirow[b]{2}{*}{ 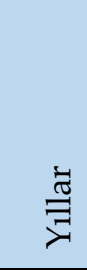 } & \multirow{2}{*}{ 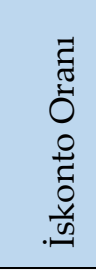 } & \multicolumn{3}{|c|}{$\begin{array}{l}\text { EA7 Sadem 3D Yazıcı Maliyetlerinin } \\
\text { İndirgenmiş Değerleri }\end{array}$} & \multicolumn{3}{|c|}{$\begin{array}{c}\text { Pax Seza 3D Yazıcı Maliyetlerinin İndirgenmiş } \\
\text { Değerleri }\end{array}$} \\
\hline & & $\begin{array}{l}\text { İşçilik } \\
\text { Maliyeti }\end{array}$ & $\begin{array}{c}\text { İlk Madde ve } \\
\text { Malzeme } \\
\text { Maliyeti }\end{array}$ & $\begin{array}{l}\text { Bakım ve } \\
\text { Onarım } \\
\text { Maliyeti }\end{array}$ & $\begin{array}{l}\text { İşçilik } \\
\text { Maliyeti }\end{array}$ & $\begin{array}{c}\text { İlk Madde ve } \\
\text { Malzeme } \\
\text { Maliyeti }\end{array}$ & $\begin{array}{l}\text { Bakım ve } \\
\text { Onarım } \\
\text { Maliyeti }\end{array}$ \\
\hline 2018 & 1,000 & $132.000,00 €$ & $280.000,00 €$ & $10.000,00 €$ & $132.000,00 €$ & $280.000,00 €$ & $6.000,00 €$ \\
\hline 2019 & 0,833 & $109.956,00 €$ & $233.240,00$ も & $12.495,00$ も & $109.956,00 €$ & $233.240,00 €$ & $6.664,00$ も \\
\hline 2020 & 0,694 & $91.608,00 €$ & $194.320,00 €$ & $11.798,00 €$ & $91.608,00 €$ & $194.320,00 €$ & $5.552,00$ є \\
\hline 2021 & 0,579 & $76.428,00$ も & $162.120,00$ も & $11.580,00 €$ & $76.428,00 €$ & $162.120,00 €$ & $5.211,00$ も \\
\hline 2022 & 0,482 & $63.624,00 €$ & $134.960,00 €$ & $11.086,00 €$ & $63.624,00 €$ & $134.960,00 €$ & $5.302,00 €$ \\
\hline 2023 & 0,402 & $53.064,00$ є & $112.560,00 €$ & $10.050,00 €$ & $53.064,00$ も & $112.560,00 €$ & $4.824,00$ も \\
\hline 2024 & 0,335 & $44.220,00$ も & $93.800,00 €$ & $9.045,00 €$ & $44.220,00$ も & $93.800,00$ も & $4.355,00$ も \\
\hline \multicolumn{2}{|c|}{ TOPLAM } & $570.900,00 €$ & $1.211 .000,00 €$ & $76.054,00 €$ & $570.900,00 も$ & $1.211 .000,00 も$ & $37.908,00 €$ \\
\hline
\end{tabular}


Yukarıda Tablo 3'de ise iskonto oranı kullanılarak daha önce Tablo 2'de EA7 Sadem 3D Yazıcı ile Pax Seza 3D Yazıcıya ilişkin iş̧̧ilik, ilk madde ve malzeme maliyetleri ile bakım ve onarım giderleri net bugünkü değerlerine indirgenmiştir. EA7 Sadem 3D Yazıcının elde etme bedeli hariç işletmeye kullanım ömrü boyunca toplam maliyetinin net bugünkü değeri 1.850.954 TL (570.900+1.211.000+76.054)'dir. Pax Seza 3D Yazıcının elde etme bedeli hariç işletmeye kullanım ömrü boyunca toplam maliyetinin net bugünkü değeri ise 1.819.808 TL (570.900+1.211.000+37.908)'dir.

Tablo 4 Ürün Yaşam Dönemi Karşılaştırmalı Net Bugünkü Maliyet Değerleri Tablosu

\begin{tabular}{|c|c|c|}
\hline \multicolumn{3}{|c|}{ Ürün Yaşam Dönemi Maliyetleri } \\
\hline & $\begin{array}{c}\text { EA7 Sadem } \\
\text { 3D Yazıcı }\end{array}$ & $\begin{array}{l}\text { Pax Seza } \\
\text { 3D Yazıcı }\end{array}$ \\
\hline Alış Maliyeti & $384.000,00 €$ & $398.000,00 €$ \\
\hline Toplam Elde Etme Maliyeti & $1.857 .954,00 €$ & $1.819 .808,00 €$ \\
\hline İşçilik maliyeti & $570.900,00$ も & $570.900,00$ も \\
\hline İlk madde ve malzeme maliyeti & $1.211 .000,00 €$ & $1.211 .000,00 €$ \\
\hline Bakım ve onarım maliyeti & $76.054,00$ も & $37.908,00 €$ \\
\hline ÜRÜN YAŞAM DÖNEMİ MALIYYETİ & $2.241 .954,00 \star$ & $2.217 .808,00 €$ \\
\hline
\end{tabular}

Yukarıda görülen Tablo 4'de ise EA7 Sadem 3D Yazıcı ile Pax Seza 3D Yazıcı makinelerine ilişkin maliyetlerin her birinin net bugünkü değerleri hesaplanan ilgili tablolardan alınarak toplu olarak gösterilmiştir. Tablodan da görüleceği üzere EA7 Sadem 3D Yazıcının yaşam dönemi boyunca işletmeye toplam maliyetinin net bugünkü değeri 2.241.954 TL iken Pax Seza 3D Yazıcı'nın işletmeye toplam maliyetinin net bugünkü değeri ise 2.217.808 TL'dir.

\section{Sonuç ve Öneriler}

Ürün yaşam dönemi maliyetlemesi uzun yıllardır bilinen bir yöntem olmasına rağmen günümüzde ürünlerin çok kısa bir yaşam dönemi olması nedeniyle hala güncelliğini koruyan bir yöntemdir. Konunun güncel olması nedeniyle örnek bir vaka çalışması kapsamında yapılan araştırmada EA7 Sadem ve Pax Seza isimli 2 farklı 3D yazıcının üretim için satın alınması kararının verilmesi açısından ürün yaşam dönemi maliyetlemesi kullanılmıştır.

EA7 Sadem isimli 3D yazıcının sadece satış fiyatına bakılarak Pax Seza 3D yazıcıdan ucuz olması sebebiyle bir satın alınma yapılması durumunda işletmenin uzun vadede kaybı söz konusu olacaktır. İşletmenin kullanım dönemi boyunca katlanacağı direkt iş̧̧ilik, direkt ilk madde ve malzeme ile bakım-onarım maliyetleri dikkate alınarak, ürünlerin kullanım ömrü boyunca yapılacak harcamalar toplamı alınmıştır. Bulunan tutarlar iskonto oranı ile net bugünkü değere indirgendiğinde ise satın alınırken pahalı görünen Pax Seza 3D yazıcının aslında işletme için ürün yaşam dönemi boyunca daha az maliyetli olması nedeniyle satın alınması gereken seçenektir.

İşletmelerin satın alma ya da üretim kararlarını vermeden önce pazar araştırmaları sonucunda ve daha önceki yıllardan edindikleri tecrübeler ile elde ettikleri tahmini veriler kullanılarak ürün yaşam dönemi maliyetleme analizinin yapılması olası zararların daha gerçekleşmeden önüne geçilmesi noktasında işletmelere önemli fırsatlar sunmaktadır.

Ürün yaşam dönemi maliyetlemesi hem üretici hem de tüketici bakış açısıyla uygulanılabilecek bir yöntemdir. Çalışma çeşitli araştırma sınırlılıkları altında gerçekleştirildiğinden, sadece bir üreticinin yeni makine alma kararı üzerinden vaka çalışması yapılarak gerçekleştirilmiştir. Gelecekte yapılacak çalışmalarda üretim aşamasındaki bir veya birden çok ürünün yaşam dönemi boyunca maliyetlerinin aynı anda hem üretici hem de tüketici açısından incelenmesi araştırmacılar ve uygulamacılar için farklı bir yol haritası oluşturulabilir. 


\section{Kaynakça}

Altınbay, A., (2006). Stratejik Maliyet Yönetimi Yaklaşımlarından Yaşam Seyri Maliyetleme Sisteminin Tasarımı ve Bir Uygulama, Yayımlanmamış Doktora Tezi, Dumlupınar Üniversitesi, Sosyal Bilimler Enstitüsü, Kütahya.

Ayyıldız, G., (2010). Mamül Yaşam Seyri Boyunca Maliyetleme ve Bir İşletme Uygulaması, Yayımlanmamış Yüksek Lisans Tezi, Sakarya Üniversitesi, Sosyal Bilimler Enstitüsü, Sakarya.

Barringer, 2003: 4 Barringer, H. P. (2003). A life Cycle Cost Summary. International Conference of Maintenance Societies, 20-23 May 2003, Australia, 20-23.

Caner, S., (2011). Ürün Yaşam Seyri Maliyetlemesinin Faaliyet Tabanlı Maliyetleme Temelinde Bir Örnek İşletme Uygulaması, Yayımlanmamış Yüksek Lisans Tezi, Sakarya Üniversitesi, Sosyal Bilimler Enstitüsü, Sakarya.

Çiftçi, H.N., (2012). Mamul Yaşam Dönemi Maliyetleme Yöntemi: Bir İşletme Uygulaması, Yayımlanmamış Yüksek Lisans Tezi, İstanbul Üniversitesi, Sosyal Bilimler Enstitüsü, İstanbul.

Çubuk, H., (2018), http://www.yildiz.edu.tr/ hcubuk/BDF-1.pdf (Erişim Tarihi: 25 Kasım 2018)

DERAN, A. (2008). Stratejik Bir Karar Verme Aracı Olarak Yaşam Seyri Maliyet Analizlerinin Tedarik Sürecindeki Yeri Ve Önemi. Çukurova Üniversitesi Sosyal Bilimler Enstitüsü Dergisi, 17(2), 465-484.

Dunk, A. S. (2004). Product Life Cycle Cost Analysis: The Impact Of Customer Profiling, Competitive Advantage, and Quality of IS Information. Management Accounting Research, 15(4), 401-414.

Emblemsvag, J. (2003). Life-Cycle Costing: Using Activity-Based Costing and Monte Carlo Methods to Manage Future Costs and Risks. New Jersey, John Wiley \& Sons.

Erden, S.A. (2004). Stratejik Maliyet Yönetimi, İstanbul, Türkmen Kitabevi.

Otlu, F. ve Karaca, S. (2005). Maliyet Yönetimi ve Yaşam Seyri Maliyet Analizi. Süleyman Demirel Üniversitesi İktisadi ve İdari Bilimler Fakültesi Dergisi, 10(2), 254-270.

Gersil, A., (2006), Stratejik Maliyet Yönetimi Kapsamında Ürün Yaşam Seyri Maliyet Yönteminin Analizi ve Bir İşletme Uygulaması, Yayımlanmamış Yüksek Lisans Tezi, Ankara Üniversitesi, Sosyal Bilimler Enstitüsü, Ankara.

Góralczyk, M., \& Kulczycka, J. (2005). LCC Application in the Polish Mining Industry. Management of Environmental Quality: An International Journal, 16(2), 119-129.

Gül, C.B. (2004), Uluslararası Ürün Yaşam Eğrisi Teorisinin Uygulanabilirliğine İlişkin Ampirik Bir Araştırma, Yayımlanmamış Yüksek Lisans Tezi, Hacettepe Üniversitesi, Sosyal Bilimler Enstitüsü, Ankara.

Güneş, R., ve Aksu, A.G.İ. (2003). Mamul Yaşam Seyri Maliyetlemesi. Süleyman Demirel Üniversitesi İktisadi ve İdari Bilimler Fakültesi Dergisi, 8(2), 43-61.

Gürdal, K. (2007). Maliyet Yönetiminde Güncel Yaklaşımlar, Ankara, Siyasal Kitabevi.

İşbankası, (2018), https://www.isbank.com.tr/TR/fiyatlar-ve-oranlar/turk-lirasi-bono-tahvil/hazine-bonosuve-devlet-tahvilleri/Sayfalar/hazine-bonosu-ve-devlet-tahvilleri.aspx (Erişim Tarihi: 25 Kasım 2018)

James, K.L., (2003). Environmental Life Cycle Costs in the Australian Food Packaging Supply Chain, Yayımlanmamış Doktora Tezi, Victoria University, School of Accounting and Finance, Avusturalya.

Kawauchi, Y., \& Rausand, M. (1999). Life Cycle Cost (LCC) Analysis in Oil and Chemical Process Industries. Toyo Engineering Corp, Chiba. https://www.researchgate.net/profile/Yoshio Kawauchi/publication/228594034 Life Cycle Cost LC $\mathrm{C}$ Analysis in Oil and Chemical Process Industries/links/5409695f0cf2718acd3d0dd4.pdf (Erişim Tarihi: 5 Kasım 2018)

Korpi, E., \& Ala-Risku, T. (2008). Life cycle costing: a review of published case studies. Managerial Auditing Journal, 23(3), 240-261. 


\section{E. Okutmuş 11/1 (2019) 216-226}

Luo, L., Van Der Voet, E., \& Huppes, G. (2009). Life cycle assessment and life cycle costing of bioethanol from sugarcane in Brazil. Renewable and sustainable energy reviews, 13(6-7), 1613-1619.

Yılmaz, R. ve Arı, M. (2011). Ürün yaşam seyri maliyet analizi ve ürün yaşam seyri maliyetleme yaklaşımları için durum değerlendirmesi ve kavramsal çözümleme ihtiyacı. Journal of Accounting \& Finance, (49). 75-88. 